tissue was not greatly different from that of young root tissues, and the average respiration rato of the bacteria corresponded to or was even lower than that of resting rhizobia $\left(Q_{\mathrm{O}}\right.$, usually about $\left.6-8\right)$. in culture. Considering, furthermore, that nodules usually represent only 1-5 per cent of the total dry weight of the plant, it is obvious that the bacteria in the nodules oxidize only a small portion (see earlier discussion $^{1}$ ) of the carbohydrate synthesized by the host plant. The bulk of the carbohydrato supply that largely determines the magnitudo of nitrogen fixation is actually used by tho host in its growth processes.

A detailed account of these investigations will be published shortly in a series of papers.

Franklin E. Allison. C. A. Ludvig.

SAM R. HoOver.

Francis W. MINOR.

Bureau of Agricultural Chemistry and Engineering, U.S. Department of Agriculture, Washington, D.C.

Aug. 28.

Allison, Soil Sci., 39, 123-143 (1935).

2 Allison and Ludwig, J. Amer. Soc. Agron., 81, 149-158 (1939)

- Ludwig, Allison, Hoover and Minor, "Incldental Observations Regarding the Production and Utilization of Alcohol by Plant Tissues". Science. In the press.

\section{Correlation between Seed Weight and 'Adult' Weight in Tomatoes}

IN a recent contribution to the study of heterosis, Luckwill ${ }^{1}$ adduces evidence that in different crosses of tomatoes hybrid vigour may appear at different stages in the life-cycle. Ho states that in certain crosses "there was found to be very little corrospondence between the presence of heterosis in the seed and in the mature hybrid". A possible reason for this, as Iuckwill mentions, is that seed size is influenced by other than genetic causes, but there is another explanation which has been overlooked, and which is important in all such studies of plant growth.

In Luckwill's experiments seeds of known weight were planted in pots, and were afterwards trans. planted "with the greatest possible care" into garden plots. Isuckwill assumes that the disturbance in growth due to transplanting does not interfere with any correlation between seed weight and adult weight, and that if seed weight is important in dotermining size, larger seeds should give rise to larger plants, notwithstanding this treatment. Tho follow. ing data show that this assumption is incorrect.

COVARIAXCE OF SEED TEIGHT AND ADULT TEIGHT FOR TEX STRAISS OF TOKATOES, BETWEEX MEANS OF STRANS.

\begin{tabular}{|c|c|c|c|}
\hline Treatment & $\begin{array}{c}\text { Degrees of } \\
\text { freedom }\end{array}$ & $\begin{array}{c}\text { Sums of } \\
\text { products }\end{array}$ & $\boldsymbol{r}$ \\
\cline { 1 - 3 } $\begin{array}{c}\text { Transplanted } \\
\text { Control }\end{array}$ & 9 & $\begin{array}{c}18 \cdot 8193 \\
28 \cdot 7683\end{array}$ & $\begin{array}{l}0 \cdot 503, \text { not signiflcant } \\
\mathbf{0} \cdot 949, \text { significant }\end{array}$ \\
\hline
\end{tabular}

Weighed seed of ten strains of tomatoes (five inbred lines and five $F_{1}$ crosses) were planted in uniform conditions in a greenhouse. After an interval of 31 days half the seedlings wero transplanted with great care into ten-inch pots. The other half remained in the ten-inch pots in which they had germinated. The transplanted and control seedlings were arranged in blocks in a greenhouse, to facilitate statistical analysis. On the 78th day after germination, as the first flowering truss appeared, the plants were harvested, dried in a stream of air at $95^{\circ}$, and weighed. The accompanying table shows the result of an analysis of covariance between seed weight and adult weight for the transplanted and control plants.

It is clear that thero is a highly significant correlation between seed weight and dry weight at the onset of flowering, and that this correlation is destroyed if the plants are transplanted between sowing and harvesting, however carefully the transplanting is carried out. It seems obvious that Luckwill's method of comparing the significance of differences of means of seed weight on one hand, and of means of fresh weight 145 days after planting, and after transplanting, on the other hand, can give no reliable information as to the relation botween seed size ( $w$ hether in bybrids or inbred lines) and adult size.

A full account of these experiments will shortly be published.

Eric Asnby.

\section{Botany School,}

University of Sydney. Aug. 28.

1.Luckwill, L. C., J. Gen., 37, 421 (1939).

\section{Loaded Dice}

Dice have been used as a game of chance from time immemorial and have in all ages been associated with gambling for high stakes. Loaded dice or dice adjusted to increase the probability of a particular face or one of $a$ group of faces turning up have been used by swindlers from very early times, and such methods of destroying symmetry as unsymmetrical weighting and slight alteration of form are well known. Even in the case of normal dice, the method of numbering tho sides may cause $n$ slight departure from perfect symmetry, and there may be justification for the alleged belief of professional gamblers that there is a slight tendency for the higher numbers 4,5 and 6 to turn up more often than 1,2 and 3 .

Dice are numbered in such a way that the sum of the numbers on opposite sides is always 7. There are two possible arrangements which are mirror images of each other, but I do not know whether both are used. The numbers 1, 2 and 3 are grouped around one corner of the cube and the opposite numbers 6,5 and 4 around the diametrically opposite corner. It follows that if conical or hemispherical holes are used for numbers, since moro material is removed the higher the number, the centre of gravity will be displaced towards the corner adjoining the three low numbers, and there should in consequence be a slight bias in favour of the higher numbers turning up, tho magnitude of the bias being increased with the size of the holes. There should also be a bias, though very much smaller, in favour of even numbers against odd numbers.

Attempts to detect such a bias by a very large number of throws have, I believe, been recorded, but I am unable to trace such records. Experimental detection of a bias would not show, however, that the bias was due to displacement of the centre of gravity, since another and very important factor is involved, namely, lack of uniformity in the frictional resistance of the surfaces of the die. 